\title{
Perspectives on Performance Management
}

\section{Dear readers,}

Presenting a research paper at international conference and publishing it in the prestigious academic journal, both represent outstanding opportunity for researchers to bring out their research results and share them with other experts. It is really valuable tradition to publish sound and innovative conference papers in leading academic journals. Thanks to such tradition, progressive ideas can be disseminated all over the researchers' community and thus, the journals can initiate and support future research directions. Considerable synergy effect can be realized as the result of such mutual collaboration.

Following these reasons, it is our great pleasure to introduce this volume of European Financial and Accounting Review which includes selection of papers presented at the research forum of $5^{\text {th }}$ International Conference Integrating Perspectives on Performance Management. Selection of papers is based on careful peer review among 25 papers presented at the conference. The conference has been organized by Management Accounting Department and under the auspices of Prof. Richard Hindls, rector of the University of Economics, Prague from $10^{\text {th }}$ to $12^{\text {th }}$ September 2008 .

Papers published in this volume show the variety of topics corresponding to performance management issues. The reason for that is evident. In global economy with strong competitive pressures, concepts and methods for managing and controlling all external as well as internal performance factors and determinants shall be considered in an integrated business performance management system. To achieve the organizational performance goals belongs to crucial dimension of everyday job for each manager and executive rather than to task for individuals in finance and controlling area.

Browsing the papers, many particularly interesting topics are announced. 
In the first paper Bartłomiej Nita is searching for the comprehensive set of criteria - requirements which should be fulfilled by modern corporate performance management system regardless of concrete type of organization.

Following the same issues Jaroslav Wagner deals with "conceptual framework questions" which should be serviceable as start-point for design and analysis of the performance measurement system.

Financial markets belong to really important sector of business nowadays. The next paper of Eleftherios Thalassinos analyses how changes in European financial sector influence the requirements on their organizational performance.

Shifting our attention to public educational sector, in the last paper, Sanna Pekkola and Juhani Ukko aim to create a measurement system which can be used for evaluating the effectiveness and innovative capability of the university consortium.

How to set appropriate transfer price in large multibusiness enterprises? Analyzing relevant implication Tomáš Buus and Jaroslav Brada focus on optimal transfer price setting.

The papers make evident the two recent tendencies in performance management research. The authors join to co-operate on international basis and the applied methods confirms that they respect interdisciplinary approach.

Let us enjoy the reading and feel free to discuss the papers critically!

prof. Ing. Bohumil Král, CSc.

Ing. Jaroslav Wagner, Ph.D.

member of Editorial board of member of organizational committee European Financial and Accounting Journal of $5^{\text {th }}$ international conference

Journal
and head of
Department of Managerial
Accounting
Integrating Perspectives on Performance Management and member of Department of Managerial Accounting 